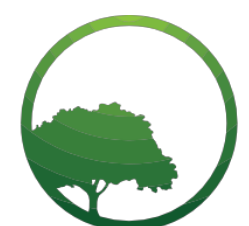

Business \& Social Science IJRBS

\section{Research in Business and Social Science}

IJRBS Vol 7 No 3, ISSN: 2147-4478

Contents available at www.ssbfnet.com/ojs

\title{
An Investigation on Entrepreneurial Competencies of Creative Industry in Bandung, Indonesia
}

\section{Bob Foster}

Universitas Informatika Dan Bisnis Indonesia, Bandung, 40614, Indonesia.

\begin{abstract}
The previous research reveals the significant influence of entrepreneurial competencies on entrepreneur's performance. This finding indicates that there should be further exploration of entrepreneurial competencies. This study aims to determine the entrepreneurial competencies regarding the process. Moreover, this research uses the quantitative approach with non-parametric structural equation modeling. The population of this study is the creative industry in Bandung. The research samples are 119 entrepreneurs in the creative industry. This study finds that some competencies are the components that create the entrepreneurial competencies of creative industries entrepreneurs in Bandung. The components are Relationship Competencies, Opportunity Competencies, Strategic Competencies, Human Competencies and Personal Strength Competencies. The research implication recommends increasing the value of the creator's components of entrepreneurial competencies. Hence, they have implications on the performance of MSMEs in the sector of creative industry in Bandung.
\end{abstract}

Key words: Entrepreneurs, Entrepreneurial Competency, Creative industry

JEL classification: $L 26, M 13, M 19$

Submitted: 19.08.2018 - Accepted: 10.11.2018

\section{Introduction}

In recent years, Indonesia's economic growth shows more stable and sustained improvement. The cumulative growth of Indonesian economy is also higher than the average world economic growth. Based on data released by Bank Indonesia, Indonesia's economic growth in 2017 was at $5.05 \%$. It is better than economic growth in 2016 at $5.02 \%$. Indeed, the improvement in economic growth is not separated from the increasing income and consumption of middle class and lower middle class.

The creative economy sector shows its increasing contribution to Indonesia's economic growth. In fact, this sector is predicted to be the backbone and a new force for Indonesian economy. This optimism becomes a new hope and passion for growing the potency of creative economy to overgrow and to be the competitive strengths of Indonesia's economy amid the increasingly competitive world market (Kemenparekraf, 2014).

Mostly, the entrepreneurs of the creative economy sector in Indonesia are the pioneers of Micro, Small and Medium Enterprises (MSMEs). It has been proven that in the midst of the global economic downturn, MSMEs 
has relatively strong economic resilience. Therefore, there is an assumption that MSME is one of the supporting sectors for the stability of the Indonesian economy. On the other hand, the development of MSMEs sector also creates the new economic resources, equalizes commercial distribution in every social class, reduces the economic inequality to materialize social justice and encourages regional economic development to create new jobs field as a form of poverty reduction. It comes with the principle of community empowerment to achieve national welfare. The magnitude of MSMEs sectors' role to current GDP is approximately 852 trillion rupiahs. Moreover, it can absorb about 15 million jobs. Besides, about 7.73 trillion rupiahs from tax of MSMEs becomes the state revenue.

MSMEs is a capable media in introducing original products in the international market through creating the added value that is originating from the image and identity of Indonesia's cultural diversity. The international market prefers MSMEs products because their products focus on quality and exclusivity. They have unique characteristics compared to products of mass production.

However, the development of this sector cope with several obstacles, such as the access to capital, lack of government support and the most important is MSMEs' low entrepreneurial competencies. Therefore, increasing the contribution of MSMEs to Indonesian economy becomes a crucial thing. It can be done by improving entrepreneurial competencies of the business communities. Several previous studies have shown that entrepreneurial competencies have a significant impact on improving business performance. Some previous studies are: Ahmad, Halim and Zainal, 2010; Chandler and Jansen, 1992; Chandler and Hanks, 1994; Chaston and Badger, 2003; Che-Rose and Abdul, 2010; Hmieleski, KM, \& Corbett, AC 2008; Machmud and Sidharta, 2016; Man, 2001; Man and Lau, 2005; Markman, Balkin and Baron, 2002; Minello, Scherer and da Costa Alves, 2014; Mitchelmore and Rowley, 2013; Rahman et al. 2015; Sadler-Smith et al. 2009; Sambasivan et al. 2010; Thongpoon, 2012; and Wu, 2009.

This research intends to know the components of MSMEs entrepreneurial competencies in the creative industrial sector by using samples of creative industry practitioners in Bandung. The previous studies reveal the differences in the components that develop the entrepreneurial competencies. The last research approaches as seen in Hazlina et al. 2010; Man, Lau and Chan, 2002; Man, 2001; Man and Lau, 2005; and Rasmussen, Mosey and Wright, 2011 show some differences.

The results indicate the gap in determining the components of entrepreneurial competencies. Further exploratory research is essential to establish a more appropriate model. It is to be applied to MSMEs in the creative industry sector. Following the circumstance, this study aims to fill the gap of previous research by predicting the components of entrepreneurial competencies in MSMEs in the creative industry sector. This research look at the dominant influence and the level of significance of each component to formulate the initial hypothesis applied in this study.

The components or the research variables that form entrepreneurial competencies in this study are Relationship Competencies, Innovative Competencies, Analytical Competencies, Opportunity Competencies, Strategic Competencies, Human Competencies, Operational Competencies, Commitment Competencies, Personal Strength Competencies and Learning Competencies.

\section{Research}

This research uses exploratory approach, and the data analysis technique is Structural Equation Model (SEM). This study applies non-parametric approach by using Partial Least Square (PLS). Population in this research is all practitioners of MSMEs in creative industry sector with sub-sector fashion in Bandung. Furthermore, this research determines the research samples through purposive sampling method with several criteria. The criteria are the business is in the creative industry sector with sub-sector fashion, the business runs for more than three years, the business is legal, and it is registered in a relevant government agency, and they are willing to be interviewed as research samples. The research samples are at least $10 \%$ of the total population. The total sample that can be processed quantitatively is 119 entrepreneurs of the creative industry. Furthermore, the researcher gave the questionnaire to the businessmen and conducted interviews directly. 
The results of data testing used in this study refer to the general criteria in Partial Least Square. It requires the value of Outer Loading Indicator $>0.5$, Average Variance Extracted value $>0.5$, Composite Reliability $>$ 0.7 and Cronbach Alpha > 0.7 (Kock, 2012).

The table exposes the test results of validity and reliability of research constructs based on AVE, Cronbach's Alpha and Composite Reliability value:

Table 1: Result of Average Variance Extracted (AVE), Cronbach's Alpha and Composite Reliability

\begin{tabular}{|l|l|l|l|}
\hline Variables & AVE & Cronbach's Alpha & $\begin{array}{l}\text { Composite } \\
\text { Reliability }\end{array}$ \\
\hline Relationship Competencies & 0.682 & 0.844 & 0.895 \\
\hline Innovative Competencies & 0.757 & 0.840 & 0.903 \\
\hline Analytical Competencies & 0.581 & 0.853 & 0.892 \\
\hline Opportunity Competencies & 0.581 & 0.756 & 0.846 \\
\hline Strategic Competencies & 0.551 & 0.880 & 0.906 \\
\hline Human Competencies & 0.537 & 0.779 & 0.851 \\
\hline Operational Competencies & 0.568 & 0.808 & 0.868 \\
\hline Commitment Competencies & 0.645 & 0.815 & 0.879 \\
\hline Personal Strength Competencies & 0.601 & 0.889 & 0.913 \\
\hline Learning Competencies & 0.553 & 0.797 & 0.860 \\
\hline
\end{tabular}

The indicators which are measured by looking at the calculation results of the outer loading value point out that some indicators have values below 0,5 . Hence, some research indicators are not used as the components that create the entrepreneurial competencies in this study. It refers to the calculation criteria of AVE, Cronbach's Alpha, and Composite Reliability.

\section{Findings}

Table two is the Path Coefficient Table

Table 2: The Value of Path Coefficients

\begin{tabular}{|l|l|l|l|}
\hline Variables & Path Coefficient & P-Value & Decision \\
\hline $\begin{array}{l}\text { Relationship Competencies } \rightarrow \\
\text { Entrepreneurial Competencies }\end{array}$ & 0.121 & 0.041 & Accepted \\
\hline $\begin{array}{l}\text { Innovative Competencies } \rightarrow \\
\text { Entrepreneurial Competencies }\end{array}$ & 0.092 & 0.095 & Denied \\
\hline $\begin{array}{l}\text { Analytical Competencies } \rightarrow \\
\text { Entrepreneurial Competencies }\end{array}$ & 0.114 & 0.051 & Denied \\
\hline $\begin{array}{l}\text { Opportunity Competencies } \rightarrow \\
\text { Entrepreneurial Competencies }\end{array}$ & 0.119 & 0.044 & Accepted \\
\hline $\begin{array}{l}\text { Strategic Competencies } \rightarrow \\
\text { Entrepreneurial Competencies }\end{array}$ & 0.134 & 0.027 & Accepted \\
\hline $\begin{array}{l}\text { Human Competencies } \rightarrow \\
\text { Entrepreneurial Competencies }\end{array}$ & 0.130 & 0.031 & Accepted \\
\hline $\begin{array}{l}\text { Operational Competencies } \rightarrow \\
\text { Entrepreneurial Competencies }\end{array}$ & 0.109 & 0.059 & Denied \\
\hline $\begin{array}{l}\text { Commitment Competencies } \rightarrow \\
\text { Entrepreneurial Competencies }\end{array}$ & 0.101 & 0.075 & Denied \\
\hline $\begin{array}{l}\text { Personal Strength Competencies } \rightarrow \\
\text { Entrepreneurial Competencies }\end{array}$ & 0.132 & 0.029 & Accepted \\
\hline $\begin{array}{l}\text { Learning Competencies } \rightarrow \\
\text { Entrepreneurial Competencies }\end{array}$ & 0.080 & 0.126 & Denied \\
\hline
\end{tabular}


Results of PLS calculation show all research hypotheses are significant with the level of alpha is 0.05 . Furthermore, figure 1 describes the overall research model:

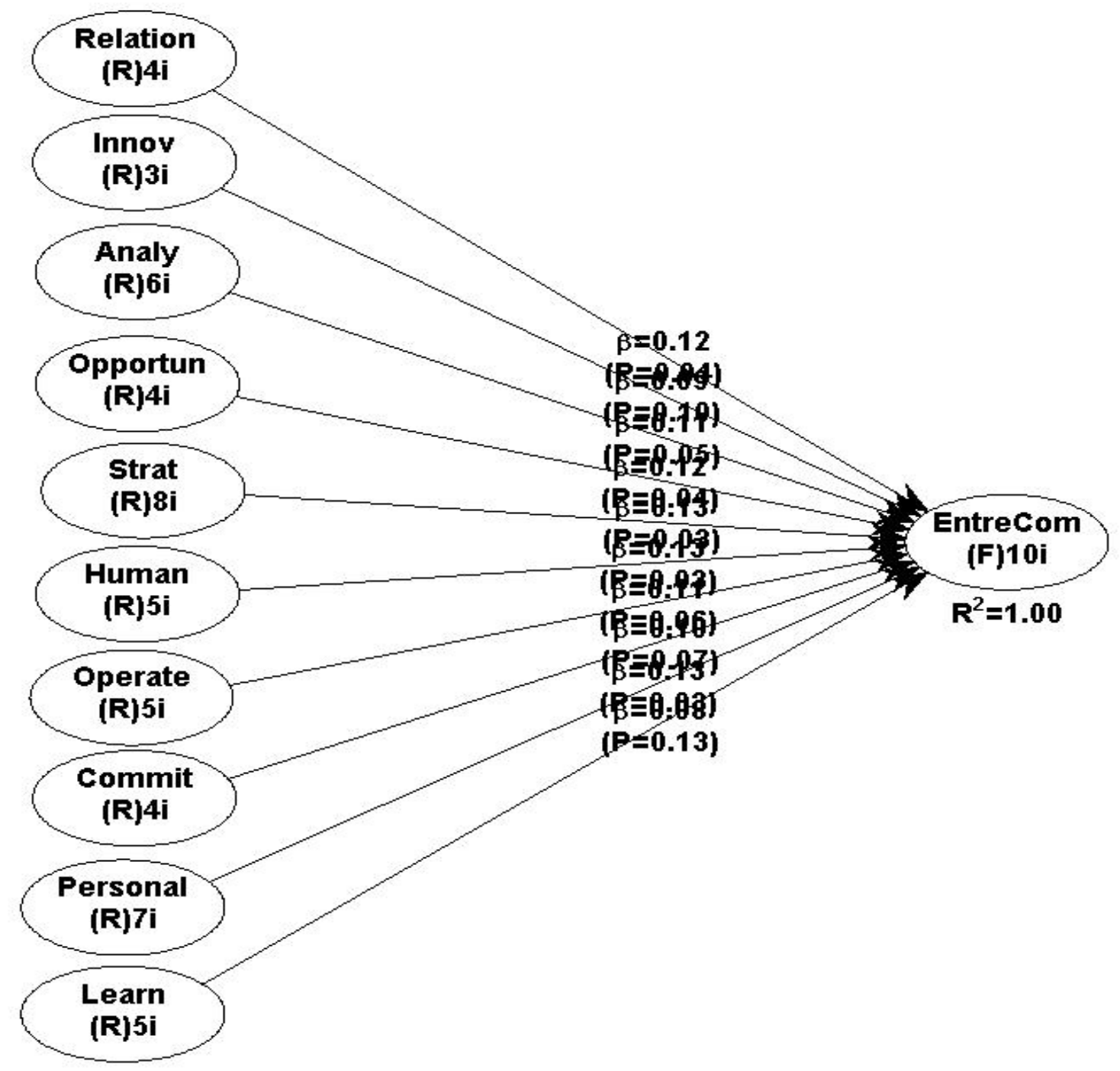

Figure 1: Structural Model of Entrepreneurial Competencies

The picture above describes the components that form the entrepreneurial competencies. The fit model is shown with Average path coefficient $(A P C)=0.113, P=0.026$ and Tenenhaus $\mathrm{GoF}(\mathrm{GoF})=0.786$. Therefore, it has perfect rating criteria.

The results reveal that Relationship Competencies, Innovative Competencies, Analytical Competencies, Operational Competencies, Commitment Competencies, Personal Strength Competencies and Learning Competencies are components that establish entrepreneurial competencies. However, the calculation results find that some components have no significant effect. Therefore, they are not used in this research. Here are the interpretation of the calculations:

(H1) Relationship Competencies. The path value of Relationship Competencies on Entrepreneurial Competencies is 0.121 with $p$-value 0.041 . The $p$-value is less than $5 \%$. Therefore, Relationship Competencies have a significant effect on Entrepreneurial Competencies. The results indicate the 
businessmen in creative industry business can develop the long-term trusting relationships in their business, successful in negotiation and can interact well with fellow businessmen and the other involved parties.

(H2) Innovative Competencies. Innovative Competencies on Entrepreneurial Competencies has a path value of 0.092 with $p$-value 0.095 . The $p$-value is greater than $5 \%$. Therefore, Innovative Competencies have no significant effect on Entrepreneurial Competencies. This shows the practitioners are still inadequate in making breakthroughs that create the high value. It is understandable since producing an innovative product takes a long process. In addition, failures occurs during the process.

(H3) Analytical Competencies. Analytical Competencies to Entrepreneurial Competencies has a path value 0.114 and $p$-value 0.051 . The $p$-value is greater than $5 \%$. Analytical Competencies have no significant effect on Entrepreneurial Competencies. This finding indicates that creative industry practitioners think divergently. They look at things from various angles so that they cannot analyze carefully.

(H4) Opportunity Competencies. Opportunity Competencies on Entrepreneurial Competencies has a path value 0.119 with $p$-value 0.044 . The $p$-value is less than $5 \%$. Opportunity Competencies have a significant effect on Entrepreneurial Competencies. Businessmen can take advantage of the opportunities and immediately implement it to be an advantage in the business. This is related to the knowledge of customers needs and activeness in finding opportunities that support their business.

(H5) Strategic Competencies. The path value of Strategic Competencies towards Entrepreneurial Competencies is 0.134 with p-value 0.027 . The $p$-value is less than $5 \%$. Therefore, Strategic Competencies have a significant effect on Entrepreneurial Competencies. Strategies undertaken by entrepreneurs in creative industry are the components that create their competence. This situation indicates that entrepreneurs of creative industries can estimate the business direction. Besides, they can anticipate the occurring changes. Also, they can arrange the concrete steps that in harmony with their business goals.

(H6) Human Competencies. Human Competencies to Entrepreneurial Competencies has a path value 0.130 with $p$-value 0.031 . The $p$-value is less than $5 \%$. It means, Human Competencies have a significant effect on Entrepreneurial Competencies. This capability is related to the labor management. This fact indicates that entrepreneurs of creative industries can manage and control their workers to achieve their business goals.

(H7) Operational Competencies. The path value of Operational Competencies to Entrepreneurial Competencies is 0.109 with $p$-value 0.059 . The $p$-value is less than $5 \%$. Thus, Operational Competencies has no significant effect on Entrepreneurial Competencies. Operational capability related to the ability in controlling the production process. The entrepreneurs can control the operations process of making products since they are supported by operational knowledge related to their business.

(H8) Commitment Competencies. Commitment Competencies to Entrepreneurial Competencies has a path value 0.101 with $p$-value 0.075 . The $p$-value is less than $5 \%$. It shows that Commitment Competencies have no significant effect on Entrepreneurial Competencies. This ability is related to the willingness to expand their business. In general, the entrepreneurs have not had a strong commitment to transform their business into a successful one. It is caused by some external factors such as technological and information advances. These factors lead to faster product recycling. It needs higher preservation to win the business competition

(H9) Personal Strength Competencies. The path value of Personal Strength Competencies on Entrepreneurial Competencies is 0.132 with $p$-value 0.029 . The $p$-value is less than $5 \%$. It means, Personal Strength Competencies have a significant effect on Entrepreneurial Competencies. The personal strengths of entrepreneur of creative industry show significant results. It indicates that entrepreneurs can self-motivate, respond to constructive criticism and identify personal strength and weaknesses and integrate them into promising business opportunities.

(H10) Learning Competencies. Learning Competencies to Entrepreneurial Competencies have a path value of 0.080 with $p$-value 0.126 . The $p$-value is less than $5 \%$. Thus, Learning Competencies have no significant effect on Entrepreneurial Competencies. This capability is related to the entrepreneurs willingness to explore their business. They need continuous learning to guarantee the business sustainability. Creative 
industry entrepreneurs are sufficient in the learning process that in connection with business improvement and sustainability.

The research model of the components that create the Entrepreneurial Competencies confirm the previous research. It has been proven that Relationship Competencies, Opportunity Competencies, Strategic Competencies, Human Competencies and Personal Strength Competencies are dominant components that influence and form MSMEs' Entrepreneurial competencies in the creative industry sector in Bandung.

Furthermore, the results of this study complement the previous researches by Hazlina et al. 2010; Lijun et al. 2014; Man, 2000; Man, Lau and Chan, 2002; Man, Lau and Snape, 2008; Man and Lau, 2005; Rasmussen, Mosey and Wright, 2011; Yushuai, Na and Changping, 2014; Zimmerman and Jiang, 2009; Rahman et al. 2015.

\section{Conclusion}

Entrepreneurial competencies are crucial components that define the success or failure of the performance and growth of a business organization, especially MSMEs that have simple organizational structures. In general, SMEs business owners have two roles. They have two roles at the same time: as the owner and the operational executor of the business. Therefore, the components of entrepreneurial competencies become the key to a successful business.

The initial hypothesis of the study states that Entrepreneurial Competencies are created from several components such as Relationship Competencies, Innovative Competencies, Analytical Competencies, Opportunity Competencies, Strategic Competencies, Human Competencies, Operational Competencies, Commitment Competencies, Personal Strength Competencies and Learning Competencies. However, the research results reveal that several components significantly influence the entrepreneurial competencies such as relationship competencies, opportunity competencies, strategic competencies, human relationship competencies and personal strength competencies. Meanwhile, the other components such as innovative competencies, analytical competencies, operational competencies, commitment competencies and learning competencies do not have a significant effect on entrepreneurial competencies of creative business practitioners in Bandung.

The results of this study provide recommendations that can be applied by entrepreneurs of creative industry sector to increase their entrepreneurial competencies such as relationship competencies, opportunity competencies, strategic competencies, human relationship competencies and personal strength competencies. Those competencies have positive and significant influences. The rising value of components that create the entrepreneurial competencies will also increase the value of entrepreneurial competencies in general. Besides, they have implications on the performance of MSMEs in the creative industry sector in Bandung.

The limitations of this study are the influences of components that form the entrepreneurial competencies. They are relationship competencies, opportunity competencies, strategic competencies, human relationship competencies and personal strength competencies that only applied to MSMEs creative industry sector in Bandung. Thus, the results of this study cannot be generalized in the other sectors and creative industries in general and in broader scopes. Due to these limitations, it is necessary to conduct similar research on the components of entrepreneurial competencies in the other sectors as well as at different research locus, both generally or specifically.

\section{References}

Ahmad, N. H., Halim, H. A., and Zainal, S. R. M. (2010). Is entrepreneurial competency the silver bullet for SME success in a developing nation. International Business Management, 4(2), 67-75.

Chandler, G. N., and Jansen, E. (1992). The founder's self-assessed competence and venture performance. Journal of Business venturing, 7(3), 223-236.

Chandler, G. N., and Hanks, S. H. (1994). Founder competence, the environment, and venture performance. Entrepreneurship theory and practice, 18(3), 77-89. 
Hazlina Ahmad, N., Ramayah, T., Wilson, C., and Kummerow, L. (2010). Is entrepreneurial competency and business success relationship contingent upon business environment? A study of Malaysian SMEs. International Journal of Entrepreneurial Behavior \& Research, 16(3), 182-203.

Hmieleski, K. M., and Corbett, A. C. (2008). The contrasting interaction effects of improvisational behavior with entrepreneurial self-efficacy on new venture performance and entrepreneur work satisfaction. Journal of business venturing, 23(4), 482-496.

Kemenparekraf. (2014) Ekonomi Kreatif: Kekuatan baru Indonesia Menuju 2025, Rencana Aksi Jangka menengah 2015-2019. Kementerian Pariwisata dan Ekonomi Kreatif, Jakarta.

Kock, N. (2012). WarpPLS 3.0 user manual. Laredo, TX: ScriptWarp Systems.

$\mathrm{Li}, \mathrm{X}$. (2009). Entrepreneurial competencies as an entrepreneurial distinctive: An examination of the competency approach in defining entrepreneurs (Doctoral dissertation, Singapore Management University).

Lijun, W., Chieh, W. T., Wanchun, D., Hongjuan, Y., and Sengui, L. (2014). Hair Dressing Entrepreneurs' Motivation, Personality and Business. International Journal of Business and Management, 127136.

Machmud, S., and Sidharta, I. (2016). Entrepreneurial Motivation and Business Performance of SMEs in the SUCI Clothing Center, Bandung, Indonesia. DLSU Business \& Economics Review, 25(2).63-78.

Man, W. Y. T. (2001). Entrepreneurial competencies and the performance of small and medium enterprises in the Hong Kong services sector. (Doctoral dissertation, The Hong Kong Polytechnic University).

Man, T. W., and Lau, T. (2005). The context of entrepreneurship in Hong Kong: An investigation through the patterns of entrepreneurial competencies in contrasting industrial environments. Journal of Small Business and Enterprise Development, 12(4), 464-481.

Man, T. W., Lau, T., and Chan, K. F. (2002). The competitiveness of small and medium enterprises: A conceptualization with focus on entrepreneurial competencies. Journal of business venturing, 17(2), 123-142.

Man, T. W., Lau, T., and Snape, E. (2008). Entrepreneurial competencies and the performance of small and medium enterprises: An investigation through a framework of competitiveness. Journal of Small Business \& Entrepreneurship, 21(3), 257-276.

Markman, G. D., Balkin, D. B., and Baron, R. A. (2002). Inventors and new venture formation: the effects of general self-efficacy and regretful thinking. Entrepreneurship theory and practice, 27(2), 149-165.

Minello, I. F., Scherer, L. A., and da Costa Alves, L. (2014). Entrepreneurial competencies and business failure. International Journal of Entrepreneurship, 18, 1-15.

Mitchelmore, S., and Rowley, J. (2013). Entrepreneurial competencies of women entrepreneurs pursuing business growth. Journal of Small Business and Enterprise Development, 20(1), 125-142.

Rahman, S. A., Amran, A., Ahmad, N. H., and Taghizadeh, S. K. (2015). Supporting entrepreneurial business success at the base of pyramid through entrepreneurial competencies. Management decision, 53(6), 1203-1223.

Rasmussen, E., Mosey, S., and Wright, M. (2011). The evolution of entrepreneurial competencies: A longitudinal study of university spin-off venture emergence. Journal of Management Studies, 48(6), 1314-1345.

Sadler-Smith, E., Hampson, Y., Chaston, I., and Badger, B. (2003). Managerial behavior, entrepreneurial style, and small firm performance. Journal of small business management, 41(1), 47-67.

Sambasivan, M., Li-Yen, L., Che-Rose, R., and Abdul, M. (2010). Venture performance in Malaysia: Personal initiative, human capital, and competency areas of founding entrepreneurs as critical success factors. Journal of Small Business \& Entrepreneurship, 23(3), 315-332. 
Thongpoon, S. (2012). Sustainable performance of Thai SMEs: Investigating the entrepreneurial competencies and sufficiency economy philosophy. Asia Pacific Journal of Management \& Entrepreneurship Research, 1(2), 5-20.

Wu, W. Wen. A competency-based model for the success of an entrepreneurial start-up. WSEAS transactions on business and economics 6.6 (2009): 279-291.

Yushuai, W., Na, Y., and Changping, W. (2014). An Analysis of Factors Which Influence Entrepreneurial Motivation Focused on Entrepreneurs in Jiang Xi Province in China. Journal of Applied Sciences, 14(8), 767-775.

Zimmerman, M., and Jiang, C. (2009). Social Competence of Women Entrepreneurs: Moderating the Effect of Social. In Human-and Reputational Capital on Entrepreneurial Success. Babson College Entrepreneurship Research Conference, Babson, Park, MA. 